\title{
Superdelayed parturition in armadillos: a new mammalian survival strategy
}

\author{
ELEANOR E STORRS, ${ }^{*}$ H P BURCHFIELD $\dagger$ \\ \& R J W REES $\ddagger$ \\ * Medical Research Institute, Florida Institute of Technology, USA; \\ $\dagger$ Research Associates, Indialantic, Florida, USA; and $\ddagger$ National \\ Institute for Medical Research, UK
}

Accepted for publication 1 June 1987

\begin{abstract}
Summary. Armadillos are generally believed to have a gestation period of 8-9 months that includes a 3- to 4-month period of embryonic diapause. Nevertheless, 21 females bore litters 13-24 months after capture and subsequent isolation from males. Two of these animals were pregnant in successive years. Evidence is presented that this is a facultative survival mechanism, induced by stress, that has not been previously reported among mammals.
\end{abstract}

\section{Introduction}

Armadillos (Dasypus novemcinctus) are placental mammals (Order Xenarthra) that are usually monestrous and monovular. ${ }^{1}$ In North America, parous females ovulate during July and August and nulliparous animals in November. After summer ovulation and mating, embryos develop to the blastocyst stage and then enter a diapause period of 3-4 months. Implantation of a single blastocyst usually takes place in late November or early December, ${ }^{1}$ after which the cell mass buds twice to yield 4 embryos. ${ }^{2,3}$ Monozygous quadruplets are born in the spring about 5 months after implantation. ${ }^{1}$ Thus gestation is believed to last for $8-9$ months including embryonic diapause. However, we have found that some females bear young 1-2 years after the generally accepted time for parturition, a phenomenon not previously reported among mammals.

\section{Materials and methods}

This finding resulted from the use of wild-caught armadillos in leprosy research ${ }^{4}$ so that large numbers of them are housed in laboratories throughout the world. To minimize injuries, all animals in our colonies in Florida and England were housed separately in plastic cages for $1-3$ years before they were killed for harvest of leprosy bacilli. Cage design and the protocols used precluded copulation after capture. These procedures are described in detail elsewhere. ${ }^{5}$

Animals were collected in groups of 10-40 in Central Florida from 1979 to June 1986. The dates of capture were governed by the requirements of the leprosy programme; therefore, sampling of the wild population was not uniform from month to month. 


\section{Results}

Of 633 females that were housed in Florida, 179 (28\%) bore litters during their first parturition season in captivity.

Of 336 females that survived a second parturition season, 15 produced litters $13-20$ months after capture (Table 1). Two of these animals were also pregnant during their first year in captivity. A sixteenth animal gave birth to a litter of 4 females during her third season in captivity, 24 months after capture and 32 months after she last mated, assuming that this took place in the wild during July and August.

The birth rate among females delivering young during their second year in captivity was only $18 \%$ of that found during the first year, but under some circumstances can be much higher. Eight females captured in Florida during November 1984 were sent by air freight to England in January 1985. They were shipped in separate containers and were caged individually thereafter. One of these was killed in August 1985. During the spring of 1986, five of the seven surviving animals produced litters 16 months after capture (Table 1).

The finding that $70 \%$ of the females shipped to England experienced delayed parturition indicated that this phenomenon might be induced by stress, and thus could serve as a facultative

Table 1. Litters produced by armadillos during their second $\&$ third parturition seasons in captivity

\begin{tabular}{|c|c|c|c|}
\hline Year & $\begin{array}{c}\text { Date of } \\
\text { birth }\end{array}$ & $\begin{array}{c}\text { Months } \\
\text { post-capture }\end{array}$ & $\begin{array}{c}\text { Composition } \\
\text { of litter }\end{array}$ \\
\hline 1981 & $\begin{array}{l}23 \mathrm{Mar} \\
31 \mathrm{Mar} \\
10 \mathrm{Apr} \\
14 \mathrm{Apr}\end{array}$ & $\begin{array}{l}16 \cdot 2 \\
17 \cdot 7 \\
17 \cdot 8 \\
16 \cdot 9\end{array}$ & $\begin{array}{l}3 \mathrm{M} \\
3 \mathrm{~F} \\
3 \mathrm{U} \\
4 \mathrm{~F}\end{array}$ \\
\hline 1982 & 7 Jan $\ddagger$ & $12 \cdot 7$ & $4 \mathrm{M}$ \\
\hline 1983 & $\begin{array}{l}21 \text { Mar } \\
31 \text { Mar } \\
4 \text { May }\end{array}$ & $\begin{array}{l}15 \cdot 6 \\
19 \cdot 9 \\
15 \cdot 8\end{array}$ & $\begin{array}{l}\mathrm{UU} \\
4 \mathrm{M} \\
4 \mathrm{M}\end{array}$ \\
\hline 1984 & $\begin{array}{l}26 \mathrm{Mar} \\
25 \mathrm{Apr}\end{array}$ & $\begin{array}{l}12 \cdot 7 \\
15 \cdot 2\end{array}$ & $\begin{array}{l}4 \mathrm{M} \\
\mathrm{UU}\end{array}$ \\
\hline 1985 & $\begin{array}{l}1 \mathrm{Feb} \ddagger \\
11 \mathrm{Feb} \\
7 \mathrm{Mar} \dagger \\
11 \mathrm{Mar} \\
22 \mathrm{Apr}\end{array}$ & $\begin{array}{l}12 \cdot 6 \\
24 \cdot 3 \\
13 \cdot 7 \\
14 \cdot 0 \\
15 \cdot 2\end{array}$ & $\begin{array}{l}4 \mathrm{M} \\
4 \mathrm{~F} \\
3 \mathrm{~F} \\
\mathrm{UU} \\
4 \mathrm{~F}\end{array}$ \\
\hline 1986 & $\begin{array}{l}15 \mathrm{Feb}^{*} \\
1 \mathrm{Mar}^{*} \\
4 \mathrm{Mar}^{*} \\
11 \mathrm{Mar}^{*} \\
18 \mathrm{Mar}^{*} \\
30 \mathrm{Mar}\end{array}$ & $\begin{array}{l}15 \cdot 4 \\
15 \cdot 8 \\
15 \cdot 9 \\
16 \cdot 2 \\
16 \cdot 3 \\
16 \cdot 7\end{array}$ & $\begin{array}{l}4 \mathrm{M} \\
\mathrm{UU} \\
4 \mathrm{~F} \\
4 \mathrm{M} \\
4 \mathrm{M} \\
2 \mathrm{M}\end{array}$ \\
\hline
\end{tabular}

\footnotetext{
* Born in England.

$\dagger$ In third parturition season.

$\ddagger$ Found in necropsy.

$\mathrm{M}$, males; F, females; U, unknown due to cannibalism by
} dams. 
survival mechanism. Major stresses to which these animals are subjected are capture and, where applicable, shipment to other laboratories. On relating month of capture to incidence of delayed births it was found that 20 delayed births occurred among 204 animals procured from November to February (Table 2). Of 132 animals captured from March to October, only one exhibited delayed parturition.

Insight into this phenomenon can be gained by relating the month of capture to birth rates during the first parturition season in captivity. A bimodal distribution with a minimum in November is obtained (Figure 1). Only 5\% of animals captured during ovulation months (July and August) bore young the following spring, whereas $17 \%$ of animals captured during embryonic diapause (September and October) had litters. Productivity fell to $7 \%$ for November captures, the month during which blastocyst implantation most of ten takes place, but increased to $32 \%$ for December captures. The birth rate peaked at $52 \%$ for animals captured in February, but declined thereafter, since many bore young in the wild before capture.

November is a critical month as shown by the finding that only $7 \%$ of females captured then had litters during their first year in captivity, compared to $18 \%$ in the second year. Of 17 females captured in November of 1984, none had young the following spring. However, of 12 animals that survived a second season in captivity, 6 produced litters. For all other months, first-year births predominated overwhelmingly. This suggests that an additional year of diapause is induced by capturing animals when blastocyst implantation is at its peak, possibly because stress-induced changes of hormonal levels in newly captured animals inhibit implantation ${ }^{1,6}$ or delay postimplantation development.

The average date on which parturition occurred differed for first and second season births. The average date of first season births was May $4 \pm 20$ days based on 112 litters. The litters that were born to dams captured during parturition months (March-June) were excluded to avoid making the result biased. This date did not vary significantly with the year or month of capture, and thus is characteristic for armadillos in their first year in captivity.

The average date of delayed births was March $24 \pm 23$ days. The difference between the two dates is $41 \pm 5 \cdot 6$ days, or more than 7 standard deviations. Thus animals maintained for one year or more under standard conditions of temperature, day-length and nutrition gave birth one month earlier in the year of parturition than those newly brought in from the wild.

Reproduction delay in armadillos is of longer duration than for all other mammals. The longest period known previously was for a marsupial, the tammar wallaby (Macropus eugenii) that has an embryonic diapause of 11 months and a development period of 28 days. ${ }^{7}$ Assuming that armadillos ovulate on 1 August and undergo a 5-month period of embryonic development, reproduction delay for animals giving birth during their second season in captivity was $15 \pm 0 \cdot 8$ months. The animal

Table 2. Relation between the month of capture and the percent of females producing young during their first and second parturition seasons in captivity

\begin{tabular}{lrrrrr}
\hline & \multicolumn{2}{c}{ First season } & & \multicolumn{2}{c}{ Second season } \\
\cline { 2 - 3 } \cline { 5 - 6 } $\begin{array}{l}\text { Month } \\
\text { captured }\end{array}$ & $\begin{array}{c}\text { No. of } \\
\text { females }\end{array}$ & With young(\%) & & $\begin{array}{c}\text { No. of } \\
\text { females }\end{array}$ & With young (\%) \\
\hline Nov & 71 & 7 & & 57 & 18 \\
Dec & 41 & 32 & & 30 & 7 \\
Jan & 137 & 42 & & 87 & 7 \\
Feb & 89 & 52 & & 30 & 7 \\
Others & 295 & 19 & & 132 & 61 \\
Total & 633 & 28 & & 336 & 6 \\
\hline
\end{tabular}




\section{Month of Capture vs Litters Produced During First Season in Captivity}

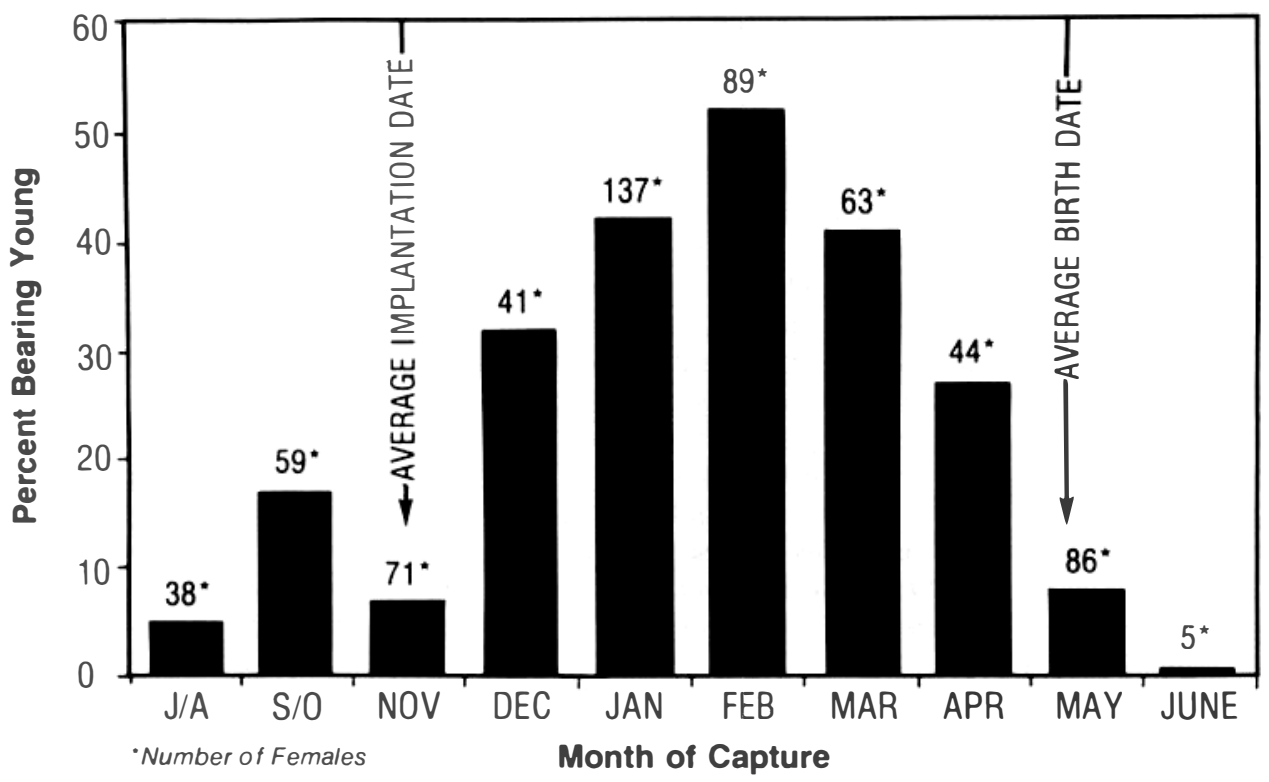

Figure 1.

that produced young during her third season had a delay of 23-24 months. Thus delay in armadillos can extend into successive parturition seasons, while the reproduction cycle of the wallaby is completed within one year. Also, wallaby blastocysts resume growth in the current season if the young in the pouch dies or is otherwise removed, while delay in armadillos persists until the following implantation season.

\section{Discussion}

The most probable explanation of delayed parturition in armadillos is that stresses experienced during the peri-implantation period prolong the generally accepted diapause of 3-4 months for an additional year, and in one case 2 years. However, this does not explain why 2 females were pregnant in successive years. Diovulation in armadillos is rare, ${ }^{1,3}$ nevertheless, it is possible that two fertilized ova were produced by each female during the same year, and one was stored for 15 months while the other developed. Alternately, ova could have been produced in successive years, and the later ones fertilized by sperm that remained viable in the reproductive tracts of the females. Thus superdelayed embryo activation combined with diovulation or delayed fertilization provide working hypotheses that can be used to design studies on in vivo storage of embryos and gametes.

Discovery of superdelayed parturition helps to clarify anomalies in the reproduction strategy of armadillos. Basically, they lean heavily toward ' $\mathrm{K}$ ' selection. This conclusion is based on bodyweight (3-5 kg), time required to reach sexual maturity (29 months), longevity (10-12 years), monovularity, implantation of only one blastocyst each year, long gestation period and birth of precocial young. However, armadillos also have characteristics that link them with ' $r$ ' selected 
species. Thus they have the lowest encephalization quotient among Xenarthrans (0.371) and one of the lowest among mammals. ${ }^{8}$

This combination of relatively small brain size with low birth rate would be expected to limit their range and reduce prospects of species survival. Instead, D. novemcinctus is by far the most successful Xenarthran, and in the last century and a half has expanded its range from a small bridgehead in South Texas to all of the Gulf Coast and many contiguous states of the United States. ${ }^{9}$

Capacity to implant only one embryo each year could presage extinction in a species in which maternal care is minimal. However, evolutionary development of polyembryony, unique to Dasypodinae, increased birth rate 4-fold and at the same time insured preservation of individual genomes by natural cloning. Now it has been shown that female armadillos are able to bear young for one or more seasons after their last contact with males. This phenomenon could play an important role in their territorial expansion and survival of the species.

\section{Acknowledgments}

The authors appreciate the faithful cooperation of Ms Jan Stoddard who diligently supervised the Florida animal colonies and Mr A Mullard who supervised the colonies in England throughout the programme. We are grateful for the advice and encouragement of the late Professor Ralph W Wetzel and dedicate this paper to his memory. The colonies of armadillos in the UK and USA were supported by the Immunology of Leprosy (IMMLEP) component of the UNDP/WORLD BANK/ WHO Special Programme for Research and Training in Tropical Diseases. Additional support for the USA colonies was provided by the National Institute of Allergy and Infectious Diseases of the National Institutes of Health.

\section{References}

${ }^{1}$ Enders AC. The reproductive cycle of the nine-banded armadillo (Dasypus novemcinctus). In Comparative Biology of Reproduction in Mammals. Rowlands IW (ed), Zoo Soc Lond: Academic Press, 1966; pp 295310.

2 Patterson JT. Polyembryonic development in Tatusia novemcinctus. J Morphol, 1913; 24: 599-684.

${ }^{3}$ Hamlett GWD. The reproductive cycle in the armadillo. Zeitschrift fur Wissenschaftlichen. Zool Abteil Leip, 1932; 141: 143-7.

4 Storrs EE, Walsh GP, Burchfield HP, Binford CH. Leprosy in the armadillo: a new model for biomedical research. Science, 1974; 183: 851-2.

5 Storrs EE, Armadillos. In UFAW Handbook on the care and management of laboratory animals. Poole, Trevor B (ed), London: Longman, 1987; pp 229-39.

6 Nakakura K, Czekala NM, Lasley BL, Benirschke K. Fetal-maternal gradients of steroid hormones in the nine-banded armadillo. J. Reprod Fert, 1982; 66: 635-43.

7 Berger PJ. Eleven month 'Embryonic Diapause' in a marsupial. Nature, 1966; 211: 435-6.

8 Eisenberg JF. The Mammalian Radiations, paperback ed. Appendix 6, pp. 498-502. University of Chicago Press; 1983.

9 Humphrey SR. Zoogeography of the nine-banded armadillo (Dasypus novemcinctus) in the United States. Bioscience, 1974; 24: 457-62. 


\section{LEPROSY CONTROL AND FIELD WORK}

\section{Charts for multiple drug therapy (MDT) in paucibacillary and multibacillary leprosy}

In the December issue of Lepr Rev, 1987; 58: 438-9 diagrams were printed which explain the drugs, dosages and periods of treatment for paucibacillary and multibacillary leprosy, according to WHO recommendations. They are normally produced on card (A4 size) rather than paper, the information being printed on both sides, with laminating and sealing of the edges in plastic. A recent estimate in Oxford, UK, for the printing of 1000 of these charts came to about $£ 100.00$, with an additional $£ 480.00$ for laminating. They are intended for desk or clinic use by all those responsible for the implementation of MDT; they are also of value in small group teaching. Further enquiries to this Editorial Office.

\section{WHO: Disability Prevention and Rehabilitation in Leprosy, 1987}

This WHO Report (WHO/CDS/LEP 87.3) is of a consultation on disability prevention and rehabilitation in leprosy which took place in Geneva, March 1987. The two subjects were considered under the following main headings: introduction, background information and state-of-the-art, preventing and limiting disabilities, rehabilitation, research and recommendations. The list of participants was as follows:

Dr (Mrs) Brand, National Hansens's Disease Centre, Carville, LA 70721, USA; Dr S D Gokhale, International Leprosy Union, A-2, Rasadhara Co-operative Housing Society Ltd, 385 S.V.P. Road, Girgaum, Bombay-400 004, India; Dr W Felton Ross, American Leprosy Mission, One Broadway, Elmood Park, New Jersey 07407, USA; Dr Maria Leide de Oliviera, Ministry of Health, Esplanada dos Ministérios, Bloc 11, Sala 809, 70058 Brasilia, Brazil; Dr E Pupulin, Amici de Raoul Follereau, Via Borselli, 4, 40135 Bologna, Italy; Mrs J Santos Valdez, Volunteers for the Rehabilitation of the Handicapped and the Disabled Inc., 99 North Drive, Baclod City, Philippines; Dr H Srinivasan, Director, Central Jalma Institute for Leprosy, Taj Ganj, Agra-282001, India; Ms J Watson, The Leprosy Mission International, 50 Portland Place, London, W1N 4DG, UK.

\section{Leprosy Control in the People's Republic of China}

Dr Ma Haide, Chairman of the China Leprosy Association/Foundation, Hou Hai Bei He Yan 24, Beijing, People's Republic of China, recently wrote with greetings and his message included the information that during 1986 they treated a further 20,000 patients, whose treatment continued for another year before release. In 1988 they anticipate that they still haveabout 80,000 patients and PRC is appealing for international support towards basic eradication by the year 2000. Contributions may be sent to the above address. Bank transfer: Bank of China, Beijing, PRC Acct. No 71405516.

\section{Drug Distribution for MDT; Stocks at Various Levels of the Health Service}

During discussions recently with Dr Cesar Viardo (Leprosy Control Service, Manila) and Dr Yo Yuasa (Sasakawa Memorial Health Foundation, Tokyo, Japan), it was noted that stocks of antileprosy drugs in the Philippines are held as follows: 24 months' supply at Department of Health level; 12 months' at Regional; 6 months' at Provincial; 3 months' at District; 2 months' at Rural Health Centre and 1 month at Barangay Health Service, i.e. the peripheral, level. These arrangements clearly relate to a particular administrative and health service structure, but they give a useful indication of periods which have been found workable in practice. If the number of cases to be treated is large and the pace of MDT implementation fast, consideration might be given to ensuring that purchase and stocking at Department of Health level, i.e. central, national, is in the order of 3 , rather than 2 years.

\section{The Use of Essential Drugs; Technical Report Series, WHO}

Technical Report Series 722, Second Report of the WHO Expert Committee on The Use of Essential Drugs is published by the World Health Organization (1985), and is obtainable from the Office of Publications, WHO, Geneva, Switzerland, or from any established medical bookshop. The contents are as follows: 1, Introduction; 2, Guidelines for establishing a national programme for essential drugs; 3, Criteria for the selection of essential drugs; 4, Guidelines for the selection of pharmaceutical dosage forms; 5, Quality assurance; 6, Drug utilization surveys; 7, Research and development; 8, Specialized applications of the essential-drugs concept; 9, Updating of lists of essential drugs; 10, Model list of essential drugs (Fourth revision)-10.1 Alphabetical list of essential drugs; 11, Changes made in revising the model list; 12, Essential drugs and primary health care-12.1 Criteria for the selection of drugs for primary health care, 12.2 A model list of drugs for primary health care; 13, Drug information and education activities-13.1 National responsibilities, 13.2 The role of WHO; and 14, Glossary of terms used in the report.

Dapsone and clofazimine are included under antileprosy drugs and rifampicin, ethionamide and prothionamide under antibacterial drugs (pages 18 and 19). 